Developing strategies and skills for responsible leadership

By: Kim S. Cameron and Arran Caza

Cameron, K.S. \& Caza, A. (2005). Developing strategies and skills for responsible leadership. In J.P. Doh \& S.A. Stumpf (Eds.), Handbook on Responsible Leadership and Governance in Global Business (pp. 87-111). Northampton, MA: Edward Elgar.

This is a draft chapter/article. The final version is available in Handbook on Responsible Leadership and Governance in Global Business edited by Jonathan P. Doh and Stephen A. Stumpf, published in 2005, Edward Elgar Publishing Ltd.

https://doi.org/10.4337/9781845425562

The material cannot be used for any other purpose without further permission of the publisher, and is for private use only.

\begin{abstract}
:
Responsible leadership is rare. It is not that most leaders are irresponsible, but responsibility in leadership is frequently defined narrowly and an important element of responsible leadership is omitted. On the one hand, the idea of responsible leadership is common, and the literature on effective leadership has always been characterized by an element of responsibility (Burns, 1978; Yukl, Gordon, \& Taber, 2002). Responsibility in this sense most often is synonymous with accountability (as in being accountable for performance), or with freedom of action, indicating that responsible individuals have discretion or volition (as in having responsibility at work). These two connotations of responsibility are closely related, as people are more likely to be accountable if they are able to act freely (Brown, 1986; Salancik \& Meindl, 1984). In these two senses, responsibility means "response-able," or possessing the capability and the accountability needed to respond. A third connotation of the concept of responsible leadership, on the other hand, is less frequently used but equally meaningful. It refers to the ability or inclination to act in an appropriate fashion. Appropriateness is key to this connotation in that it associates responsible action with what is right, correct, or beneficial. Behaving responsibly means doing good (Walsh, Weber, \& Margolis, 2003).
\end{abstract}

Keywords: responsible leadership | Positive Organizational Scholarship | positivity

Book chapter:

$* * *$ Note: Full text of article below 


\title{
DEVELOPING STRATEGIES FOR RESPONSIBLE LEADERSHIP
}

\author{
Kim Cameron and Arran Caza \\ University of Michigan \\ (May Draft)
}

Responsible leadership is rare. It is not that most leaders are irresponsible, but responsibility in leadership is frequently defined narrowly and an important element of responsible leadership is omitted. On the one hand, the idea of responsible leadership is common, and the literature on effective leadership has always been characterized by an element of responsibility (Burns, 1978; Yukl, Gordon, \& Taber, 2002). Responsibility in this sense most often is synonymous with accountability (as in being accountable for performance), or with freedom of action, indicating that responsible individuals have discretion or volition (as in having responsibility at work). These two connotations of responsibility are closely related, as people are more likely to be accountable if they are able to act freely (Brown, 1986; Salancik \& Meindl, 1984). In these two senses, responsibility means "response-able," or possessing the capability and the accountability needed to respond. A third connotation of the concept of responsible leadership, on the other hand, is less frequently used but equally meaningful. It refers to the ability or inclination to act in an appropriate fashion. Appropriateness is key to this connotation in that it associates responsible action with what is right, correct, or beneficial. Behaving responsibly means doing good (Walsh, Weber, \& Margolis, 2003).

This latter usage of responsibility places the concept in the domain of a newly emerging field of study called Positive Organizational Scholarship (POS). Positive Organizational Scholarship focuses on the investigation of what goes right in organizations (rather than what goes wrong), what is life-giving (rather than life-depleting), what is experienced as good (rather than bad), what is inspiring (rather than depressing), and what elevates individuals and systems (rather than diminishes them). Responsibility used in the first two ways is associated with achieving desired results. Used in the third way, responsibility is associated with the promotion of outcomes such as interpersonal flourishing, meaning and meaningfulness, virtuous behaviors, positive emotions, high energy connections, and appreciative inquiry in organizations (Cameron, Dutton, \& Quinn, 2003). It focuses on the highest potentiality of human systems.

\section{Responsible Leadership and Positive Organizational Scholarship}

Responsible leadership in the POS sense is unashamedly value biased. It emphasizes an affirmative orientation toward the enablement of positive human capability. Responsible leadership in the POS sense focuses on positive deviance, in that it focuses on extraordinary positive outcomes and the processes that produce them. Elements of responsible leadership using this third definition can be found in disciplines such as positive psychology (e.g., Snyder \& Lopez, 2002), appreciative inquiry (e.g., Cooperrider \& Whitney, 2000), prosocial behavior (e.g., Batson, 1994), citizenship behavior (e.g., Bolino, Turnley, \& Bloodgood, 2002), community psychology (e.g., Cowen \& Kilmer, 2002), corporate social responsibility (e.g., Margolis \& Walsh, 2003), ethics (e.g., Hursthouse, 1999), creativity (Amabile, et al., 1996), and virtue (e.g., Tjeltveit, 2004).

Responsible leadership in this positive sense is not a new orientation, of course, since positive phenomena have been studied in organization and management science for decades (e.g., Peterson \& Seligman, 2003). Yet, studies of responsible leadership leading to affirmative, uplifting, and elevating processes and outcomes have not been the norm. They have been overwhelmed in the scholarly literature by less positive topics. Responsibility associated with maintaining accountability has dominated responsibility associated with producing goodness. For example, Walsh's survey (1999) found that positive terms (e.g., virtue, caring, compassion, goodness) have seldom appeared in the business press (e.g., Wall Street Journal) in the last 17 years, whereas negatively-biased words (e.g., beat, fight, win, compete) have increased four-fold in the same period. In medicine, Mayne (1999) found that studies of the relationship between negative phenomena and health outnumbered by 11 to 1 studies of the 
relationship between positive phenomena and health. And, in psychology, Czapinski's (1985) coding of research articles found a 2 to 1 ratio of negative issues to positive or neutral issues.

Responsible leadership in the POS sense does not ignore non-positive conditions, of course, or situations when mistakes, crises, deterioration, or problems are present. Most of the time people and institutions fall short of achieving the best they can be or fail to fulfill their optimal potential. However, when organizations should fail but don't, when they bounce back but shouldn't, when they remain flexible and agile but ought to become rigid, they demonstrate positive deviance (Weick, 2003). Responsible leadership in the POS sense, therefore, focuses on enabling positive dynamics - in either conducive or challenging circumstances-and fostering the highest human potentialities.

\section{Examples of Responsible Leadership in Enabling Positivity}

Several brief descriptions illustrate the positive connotation of responsible leadership in organizational settings. They are intended to serve as concrete examples of how responsible leadership is manifested in organizations.

Timberland, a manufacturer of shoes, boots, and apparel, decided to increase substantially the percentage of organically grown cotton in its clothes in order to reduce exposure to carcinogens by migrant workers who pick corporately-grown cotton. In the absence of any customer demand or regulatory encouragement, and at a substantial expense to the company's bottom line, CEO Mark Schwartz made this decision as a matter of conscience. The intent of Timberland was to try to benefit a disadvantaged group of individuals who would likely never be customers but whose lives could be made better by Timberland's change in policy (Schwartz, 2001).

In an attempt to marry his theological and free enterprise values, Tom Chappell, founder of Tom's of Maine, created products void of dyes, sweeteners, and preservatives two decades before it became the socially accepted thing to do for health-conscious companies. He also established a policy in his firm in which ten percent of all profits and five percent of employees' time would be donated annually to charitable organizations. The motive was not public recognition or marketing advantage-since these decisions were made at a time when such moves were considered imprudent-but "just because it is the right thing to do" (Chappell, 1996).

Merck Corporation created a compound originally intended as an animal antibiotic, but scientists accidentally discovered that it was an effective cure for river blindness, a disease affecting millions of people in the developing world. With no hope of recovering the invested capital needed to create a human application, and at the risk of incurring costs associated with any unanticipated side-effects, Merck developed and distributed the drug free of charge to the developing world, thus helping to eradicate the disease (Bollier, 1996).

Greg Mortenson, using $\$ 623$ in pennies donated from American school children and $\$ 2000$ obtained by selling personal possessions, began a school building program in northern Pakistan aimed at educating formerly illiterate children, especially young women (previously forbidden from receiving an education). To merit a school, a village was required to donate the land, help build the school, and commit to increase the number of young women enrolled by 10 percent each year. In five years, Mortenson's project constructed 28 school buildings-at one quarter of the World Bank's price-and currently educates 8200 formerly-illiterate children, 3400 of whom are girls (Fedarko, 2003).

When the main buildings of Malden Mills_maker of Polar Fleece-burned to the ground one night in Massachusetts, its owner, Aaron Feuerstein, made an almost immediate announcement. He promised to continue to pay workers at full salary and to rebuild the plant in the same location, even though substantial cost savings could have been realized by rebuilding in another state or off-shore. Rather than laying off employees, he maintained full pay and benefits. The cost of this decision, coupled with escalating price competition from low-cost off-shore textile manufacturers, put the firm on the edge of bankruptcy six years later. In the midst of difficult negotiations to obtain bank loans and restructured debt, Feuerstein still indicated that he would make the same decision again today. (Derber, 2000) 
A local dentist in Columbus, Ohio, after taking over the practice of his deceased father, was involved in a serious automobile accident in which his severe injuries required him to remain bed-ridden for several months. Other dentists in the community, who were direct competitors, volunteered to come into his office to treat his patients. They were paid neither for the hours they worked nor for the patient services they provided. All income remained in the injured dentist's office for his personal use. (Schottenstein, 2003).

These brief examples are not the only forms-nor even the most common forms-of responsible leadership. Nonetheless, they illustrate the notion of responsible leadership as positive deviance, and how it can contribute to the elevation of others. The examples also differentiate this form of responsible leadership from the more common understanding of responsibility that is associated with maintaining accountability or possessing discretion.

\section{Enabling Responsible Leadership}

In addition to clarifying the meaning of responsibility, it is also important to acknowledge that leadership has a specific meaning as well. Quinn (2004) asserted that no person is a leader all of the time. Leadership is a temporary condition in which certain skills and competencies are displayed. When they are demonstrated, leadership is present. When they are not demonstrated, leadership is absent. People choose to enter a state of leadership when they choose to adopt a certain mindset and implement certain key skills.

Understanding that leadership is a temporary, dynamic state brings us to a radical redefinition of how we think about, enact, and develop leadership. We come to discover that most of the time, most people, including CEOs, presidents, and prime ministers, are not leaders. We discover that anyone can be leader. Most of the time, none of us are leaders. (Quinn, 2004:12).

Responsible leadership, then, is a temporary condition. It occurs when positive dynamics are enabled and the highest human potentialities are fostered. It can be demonstrated by almost anyone and revealed in a wide variety of circumstances. The focus of this chapter is on the strategies that are available to responsible leaders which enable and enhance positive outcomes as illustrated in Figure 1. These include: positive climate, positive calling orientation, positive connections, and positive communication. The discussion of each these four factors is followed by a brief discussion of certain practical skills or strategies that can enable them, and references to validating research is provided. The chapter concludes with a summary framework of responsible leadership and a set of research questions that can help guide future investigations.

\section{Figure 1 goes about here}

A Positive Climate. Baumeister, Bratslavsky, Finkenauer, and Vohs (2001), in a comprehensive review of psychological literature, highlighted the fact that negative occurrences, bad events, and disapproving feedback are more influential and longer lasting in individuals than positive, encouraging, and upbeat occurrences. One piece of negative feedback amidst several compliments, one significant loss amidst several important gains, one incidence of abuse amidst several incidents of nurturing, one traumatic event amidst several pleasant events, or one bad relationship amidst several good relationships all have a disproportionately negative impact on individuals and on organizations. That is, the negative event will engender more coping behaviors, longer lasting reactions, and more lingering memories than the comparable positive event.

The title of Baumeister, et al.'s review gives away its conclusion: "Bad is Stronger than Good." People tend to pay more attention to negative than positive phenomena, but for good reason. Ignoring a negative threat could be lethal. That is, from the outset of life, individuals learn that to ignore negative feedback is likely to be not only unpleasant but dangerous or even life-threatening. Ignoring the honking of a horn or the screeching of tires while crossing the street could be fatal. On the other hand, ignoring an enjoyable or pleasant occurrence would only result in regret at missing a pleasurable experience. 
Seldom does anything life-threatening occur associated with positive phenomena. Consequently, individuals in general-and especially leaders in organizations-who are constantly confronted by problems, threats, and obstacles-have a tendency to focus on the negative much more than the positive. They are socialized this way from birth. Most leaders, authority figures, or role models that people encounter are charged with resolving problems, defeating the competition, or protecting the innocent from threats (March \& Simon, 1958; Riley, 1998; Cameron, 2002a). Negative elements receive much more attention than positive elements in the environment. Responsible leaders, therefore, are unusual in that they choose to emphasize the positive, uplifting, and flourishing side of organizational life. It is not that they ignore the negative and adopt a Pollyannaish perspective, but they counter the tendency toward negativity with an abundance of positivity. In the absence of such an emphasis, negative inclinations overwhelm the positive.

Climate refers to individuals' psychological experience associated with the work environment (Denison, 1996; Smidts, Pruyin \& Van Riel, 2001), so that a positive climate is one in which positive feelings and interpretations predominate over negative feelings and interpretations. Fredrickson (1998; 2001; 2002; 2003) found, in controlled psychological experiments, that a positive climate leads to positive emotions which, in turn, lead to optimal individual and organizational functioning. These positive outcomes are produced both in the immediate term as well as over the long run. Engendering a positive climate does not depend so much on inherent attributes or events as it does on the approach adopted by the leader. Leaders have an extraordinary degree of impact on the climate, on the way others interpret their circumstances, and on the definitions of subjective well-being (Fredrickson, 2003; Diener, 1995). Consequently, leaders affect organizational climate as their personally induce, develop, and display positive emotions.

Fredrickson (1998) documented the "broaden and build" phenomenon that is associated with positive emotions. Experiencing positive emotions "broadens people's momentary thought-action repertoires and builds their enduring personal resources" (2003: 166). Negative emotions narrow people's thought-action repertoires and diminish their coping abilities. That is, inducing positive emotions (such as joyfulness, love, or appreciation) enlarges cognitive perspectives and enhances the ability of individuals to attend to more information, make richer interpretations, and experience higher levels of creativity and productivity (Isen, 1987). This also builds enduring personal resources such as intellectual complexity, knowledge, intellectual interest, and the capacity to explore (Fredrickson \& Branigan, 2001). Positive emotions also down-regulate negative emotions such as fear, anger, sadness, or anxiety and un-do their negative physiological effects (Fredrickson \& Levenson, 1998). Generating a positive climate, in other words, engenders and enhances positive emotions which, in turn, generate "upward spirals toward optimal functioning and enhanced performance" (2003: 169). A positive work climate has also been found to enhance decision making, productivity, creativity, social integration, and prosocial behaviors (Staw \& Barsade, 1993).

Enabling a Positive Climate. Responsible leaders resist the tendency to concentrate primarily on the negative, threatening, or problematic in the environment. Instead, they emphasize positive emotions and positive phenomena in the interest of developing a positive climate. Two ways to do this are by creating positive energy networks and by focusing on individuals' strengths.

Recent research by Baker, Cross, \& Wooten (2003) discovered that individuals can be identified as "positive energizers" or "negative energizers" and that the difference has important implications. Positive energizers create and support vitality in others. They uplift and boost people. Interacting with positive energizers leaves others feeling lively and motivated. In contrast, negative energizers deplete the good feelings and enthusiasm of others. They sap strength from and weaken people. They leave others feeling exhausted and diminished. Positive energizers benefit their organizations by enabling others to perform better (Baker, Cross, \& Wooten 2003). In fact, a comparison between information networks (i.e., who obtains information from whom), influence networks (i.e., who influences whom), and positive energy networks (i.e., who energizes whom) revealed that energy networks were far more predictive of success than information or influence networks (Baker, 2004). Being a positive energizer made individuals four times more likely to succeed then being at the center of an information or influence network, and this success was conveyed to those interacting with the energizer (Baker, Cross, \& Wooten 2003). High 
performing organizations have three times as many positive energy networks as average organizations (Baker, 2004).

Responsible leaders focus on creating positive energy networks, both by modeling positive energy themselves and by building positive energy networks among others. Positive energizers can be identified and placed in tasks and roles that will allow others to interact with them, thus enhancing the performance of a broadened field of employees. Negative energizers who are essential to the organization for reasons of talent or experience can be placed in non-central positions that minimize the energy-depleting effects they have on others. Leaders can also promote a climate of positivity by recognizing, rewarding, and supporting positive energizers.

A second opportunity for the responsible leaders to promote a climate of positivity lies in a focus on individual and organizational strengths. Identifying and building upon people's strengths can produce greater benefit than finding and correcting their weaknesses (Seligman, 2002; Clifton \& Harter, 2003). For example, managers who spent more time with their strongest performers, as compared to spending it with their weakest performers, achieved double the productivity. Similarly, in organizations where every day workers had a chance to do what they do best, productivity was one and a half times greater than in the typical organization (Clifton \& Harter, 2003).

The reason for this difference lies in the way that people learn. Individuals learn more readily and more completely from positive demonstrations than from negative demonstrations (Bruner \& Goodnow, 1956). In other words, telling people what not to do is less helpful than identifying what they should do. People given negative examples (i.e., told what to fix or to avoid repeating) are much more likely to do exactly what they were told not to do, simply because that is the picture in their mind. For example, if someone says, "Do not think of a white bear," the first thing to occur is a thought about a white bear. This phenomenon is known as the ideomotor reflex (Bargh \& Chartrand, 1999); that is, thinking of an action makes people much more likely to engage in that action regardless of whether they were thinking about doing it beforehand.

This phenomenon is clearly illustrated by a study of how to best enhance the performance of bowlers. In an experimental condition, people were videotaped as they bowled three games. Half the bowlers were then shown video tapes of frames when they knocked all the pins down-spares or strikes-whereas the other half of the bowlers was shown video tape of frames when they did not knock down all the pins. After a period of practice, using the video tapes as models and guides, statistically significant differences were found between the two groups. Those watching themselves succeed (i.e., making strikes) were significantly better bowlers than those who watched themselves in a non-success condition (see Cooperrider \& Srivastava, 1987). That is, people tend to learn from success more effectively and efficiently than from failure, so responsible leaders emphasize success, build on strengths, and celebrate the positive much more than spending time correcting the negative. They think on the positive, and encourage others to do so as well, thereby enabling a positive climate.

Positive Connections. Heaphy and Dutton (2004) reviewed the literature on the association between positive relationships and physiological health. Abundant evidence has linked the positive effects of social relationships with social phenomena such as power (Ibarra, 1993), career mobility (Burt, 1992), mentoring and resource acquisition (Kram, 1985), and social capital (Baker, 2000). Studies also have shown that social relationships have positive affects on longevity and recovery from illness (Ryff \& Singer, 2001). That is, positive social relationships-the uplifting connections associated with individuals' interpersonal interactions-have beneficial effects on a variety of aspects of human behavior and health. Heaphy and Dutton's literature review, however, explains one mechanism for why these positive outcomes occur. Specifically, positive social relationships affect the hormonal, cardiovascular, and immune systems of the body, thus enhancing health, wellbeing, and the nature of the relationships themselves.

Specifically, when people experience position relationships with others, oxytocin (a health enhancing hormone) is released in the body leading to lower blood pressure and heart rate and an enhanced ability to handle stress calmly (Taylor, 2002; Ryff, Singer, Wing, \& Love, 2001). Positive social contacts lessen 
the allostatic load (the physiological reaction in the body to stress), so the body works less hard to cope under the presence of stressful conditions (Epel, McEwen, \& Ickovics, 1998). In addition, the increase in anabolic hormones associated with positive relationships also has a calming effect on the body and mind (Seeman, 2001). In addition, increases in oxytocin cause people to seek social contact with others (Taylor, 2002), which, in turn, leads to a virtuous cycle of positive social contact with its attendant physiological consequences. Kiecolt-Glaser, Bane, Glaser, \& Malarkey (2003) found that the hormonal effects of positive relationships have a long term impact on marriages. Married couples were required to discuss a stressful topic and four stress-related hormones (e.g., ACTH) were measured over a 24 hour period. Ten years later, these couples were tracked down, and it was found that the hormonal levels in the original experiment predicted their marital status (married, divorced, separated). Those with elevated stress hormone levels were less likely to be married. The release of good hormones (e.g., oxytocin) and the decrease of bad hormones (e.g., ACTH) predicted relationship durability.

Similar findings have been found with regard to the effects of positive relationships on the cardiovascular system. People who experience positive relationships (as opposed to ambivalent or negative relationships) experienced lower blood pressure, systolic heart rate, and diastolic heart rate (HoltLunstad, Uchino, Smith, Olson-Cerny, \& Nealey-Moore, 2003). When encountering stressful events, people did less cardiovascular work, as evidenced by lower heart rates and blood pressure, when they were in positive relationships or felt social support at work (Brondolo, et al, 2003; Unden, Orth-Gomer, \& Elofsson, 1991). Social and emotional support at work (especially from supervisors and coworkers) had a direct effect on lowering heart rate and blood pressure (Karlin, Brondolo, \& Schwartz, 2003). Especially interesting was an investigation of caregivers for Alzheimer's patients in which persons with high levels of social support had heart rate patterns associated with lower chronological age compared to care givers with low levels of social support (Uchino, Kiecolt-Glaser, \& Cacioppo, 1992). Those with positive relationships were not as old physiologically as those without. In addition, a study of 10,000 Israeli men (Medalie \& Goldbourt, 1976) found that among those experiencing high levels of stress, those who had a loving and supportive wife had half the rate of angina pectoris (chest pain). After a heart attack, the presence of social and emotional support doubled the chances of survival six months later in another study (Berkman, Leo-Summers, \& Horowitz, 2002), and was more predictive than chronological age.

The third factor-the immune system-is also positive affected by positive relationships. Individuals in positive relationships have greater resistance to upper respiratory infections (Cohen, Doyle, Skoner, Rabin, \& Gwaltney, 1997), and men reporting greater satisfaction with their social support system had lower levels of a prostate-specific antigen which indicates various prostate diseases. Positive relationships actually enhanced the body's ability to fight off cancer (Stone, Mezzacappa, Donatone, \& Gonder, 1999). Medical students reporting higher levels of social support had stronger immune responses to Hepatitis B vaccines than those with less social support (Esterling, Kiecolt-Glaser, Bodnar, \& Glaser, 1994), and stronger immunity responses were detected in the bodies of caregivers who experienced higher levels of social support. These immune responses were due primarily to the presence of NK cells (natural killer cells) and T-lymphocytes which fight off colds and disease.

The presence of positive and supportive relationships, in sum, have positive effects on individuals and subsequently on their performance-as well as on their collective performance in an organizationbecause of their association with very basic physiological processes (see Heaphy \& Dutton, 2004).

Enabling Positive Connections. Fostering positive relationships in organizations is a topic that has been well researched in organizational studies, and many strategies have been identified. Searching the phrase "relationships at work" on Amazon.com, for example, creates more than 100,000 hits.

Buckingham and Clifton (2001) identified a key measure of positive relationships at work as captured by the item: "Do you have a best friend at work?" When a positive answer is given to this question, the positive affects of relationships mentioned above are significantly higher than when a negative answer is given. One worrisome outcome of best friends working together, of course, is that more time is spent on relationship management than on task accomplishment, but evidence suggests that this is seldom the danger that is feared (Dutton \& Heaphy, 2003). Opportunities to form friendships at work actually enhance and increase the productivity of friendship-based work groups (Dutton, 2003). 
Aside from friendships, positive relationships at work can also be facilitated by means of another set of factors whose importance was recently uncovered in research. These include the fostering of compassion, forgiveness, and gratitude in organizations.

These terms may sound a bit saccharine and soft-even out of place in a serious discussion of responsible leadership and effective performance-yet recent research has found them to be very important predictors of organizational success. Companies that scored higher on these attributes performed significantly better than others (Cameron, Bright, \& Caza, 2004). When managers fostered compassionate behavior among employees, enabled forgiveness for missteps and mistakes, and encouraged gratitude resulting from positive occurrences, their firms excelled in profitability, productivity, quality, innovation, and customer retention. Responsible leaders that reinforced these virtues were more successful in producing bottom line results (Cameron, 2003).

Compassion can be enabled, according by Kanov, et at., (2004) through three processes: collective noticing, collective feeling, and collective responding. When people experience difficulty or negative events, the first step is to notice or become aware of what is occurring, that is, to be on the lookout for colleagues who need help. Second, the expression of collective emotion can be fostered through planned events where people can share feelings (for example, grief, support, or love) which help build a climate of compassion (Frost, 1999). Third, collective responding occurs when organized action is taken to foster healing or restoration. In the aftermath of the 11 September 2001 tragedy, many examples of compassion-and non-compassion-were witnessed in organizations around the country. While some responsible leaders modeled caring and compassion in the responses they fostered, others stifled the healing process (see Dutton, et al., 2002).

Forgiveness can be enhanced in organizations (McCullough, Pargement, \& Thorsen, 2000; Worthington, 1998) when responsible leaders do at least five things. (1) Acknowledge the trauma, harm, and injustice that their organization members have experienced, but they define the occurrence of hurtful events as an opportunity to move forward toward a new goal. (2) Associate the outcomes of the organization (e.g., its products and services) with a higher purpose that provides personal significance for organization members. This higher purpose replaces a focus on self (e.g., retribution, self-pity) with a focus on a higher objective. (3) Maintain high standards and communicate the fact that forgiveness is not synonymous with tolerance for error or lowered expectations. Forgiveness facilitates excellence by refusing to focus on the negative and, instead, focusing on achieving excellence. (4) Provide support by communicating that human development and human welfare are as important in the organization's priorities as the financial bottom line. This kind of support helps employees catch sight of a way to move past the injury. (5) Pay attention to language, so that terms such as forgiveness, compassion, humility, courage, and love are acceptable. This language provides a humanistic foundation upon which forgiveness can be developed. An analysis by Cameron and Caza (2003) of the several organizations' successful turnarounds after the trauma of downsizing revealed these strategies as being demonstrated in institutionalized forgiveness.

Observing acts of compassion and forgiveness—not to mention being the recipient of them-creates a sense of gratitude in people, which has been found to have dramatic effects on individual and organizational performance. For example, Emmons (2003) induced feelings of gratitude in students by assigning them to keep journals as part of a semester-long assignment. Some of the students were required to keep "gratitude journals" on a daily or weekly basis. That is, they wrote down events or incidents that happened during the day (or week) for which they were grateful. Other students were assigned to write down events or incidents that were frustrating, and still other students were assigned to write down events or incidents that were merely neutral. Students keeping gratitude journals, compared to frustrated students and neutral students, experienced fewer physical symptoms such as headaches and colds; felt better about their lives as a whole; were more optimistic about the coming week; had higher states of alertness, attentiveness, determination, and energy; reported fewer hassles in their lives; engaged in more helping behavior towards other people; experienced better sleep quality; and had a sense of being more connected to others. In addition, they were absent and tardy less often and had higher grade point averages. Feelings of gratitude had significant impact on student classroom performance as well as people's personal lives. Emmons also found that expressions of gratitude by one 
person tend to motivate others to express gratitude, so a self-perpetuating, virtuous cycle occurred when gratitude was expressed. Gratitude elicited positive behaviors on the part of other people (e.g., they were more likely to loan money, provide compassionate support) as well as behave reciprocally. For example, a hand-written "thank you" on a restaurant bill by the server elicited about 11 percent higher tips, and visits by case workers and social workers was 80 percent higher if they are thanked for coming (McCullough, Emmons, \& Tsang, 2002).

Responsible leaders can engender positive relationships in organizations, therefore, merely by modeling and encouraging acts of compassion, collective forgiveness, and expressions of gratitude, as well as by encouraging the formation of friendships at work. As demonstrated by Heaphy \& Dutton (2004), such activities produce physiological effects which motivate people toward higher performance as well as fostering virtuous cycles of enriched relationships.

Positive Communication. Positive communication occurs in an organization when affirmative and supportive language replaces negative and critical language. The power of positive communication is illustrated in a study of 60 management teams who were engaged in their annual strategic planning and budget-setting activities (Losada \& Heaphy, 2004). The research focused on investigating why some teams and organizations performed better than others.

Teams were categorized into effectiveness levels based on three measures of performance: profitability, customer satisfaction, and 360-degree evaluations of the managers comprising the teams. The three groups were high performing teams $(\mathrm{N}=15)$, average performing teams $(\mathrm{N}=26)$, and low performing teams $(\mathrm{N}=19)$, based on how they scored on the three criteria. To explain differences among the teams, the communication patterns of team members were carefully monitored and categorized by trained raters who were unaware of the performance category of the teams. Four communication categories were used: the ratio of positive to negative comments, the ratio of inquiry to advocacy comments, the ratio of focusing on others compared to focusing on self, and a measure of "connectivity," or the amount of interaction and information exchanged in the team.

The single most important factor in predicting team performance-which was more than twice as powerful as any other factor-was the ratio of positive comments to negative comments. Positive comments are those that express appreciation, support, helpfulness, or compliments. Negative comments express criticism, disapproval, or blame. The results of the research showed that in high performing teams, the ratio of positive to negative comments was 5.6 to 1 . Five times more positive comments were made than negative comments in high performing teams. In medium performing teams, the ratio was 1.85 to 1 . In low performing teams, the ratio was 0.36 to 1 . In low performing teams, in other words, there were three negative comments for every positive comment.

These results demonstrated that high performing teams had very different communication patterns than low performing teams_-primarily based on the abundance of positive comments. Effective teams were far more complimentary and support than low performing teams. It was not that correction and criticism were entirely absent-that is, these teams were not characterized by a Pollyannaish or rose-colored glasses approach to strategic planning. The ratio, it is important to point out, was not 5 to 0 , nor 20 to 1 ; rather, the ratio was constrained at between approximately 3 to 1 and 9 to 1 . Corrective and disagreeing communications were certainly present in high performing teams but just not to the point of dominating or overwhelming the positive (Fredrickson \& Losada, 2004). Teams that performed moderately well had about an equal number of positive and negative comments, and teams that performed poorly were more negative than positive (Losada \& Heaphy, 2004).

This same 5 to 1 ratio was discovered by Gottman (1994) in his predictive studies of successful marriages and divorces. The best predictor of the sustainability and quality of the marital relationship was found to be the ratio of positive to negative communication events. The "Gottman index", in fact, has made the 5 to 1 ratio quite well-accepted in family therapy and family sociology. Marriages that end in divorce, similar to the Losada \& Heaphy (2004) study, are typified by more negative than positive communications (Gottman, 1994). 
One explanation for the performance effects of positive communication is that positive communication has been found to create significantly more "connectivity"-i.e., the exchange of information, interpersonal interactions, and positive emotions-in organizations. This connectivity is the means by which resources flow and coordinated action takes place (Losada \& Heaphy, 2004). This coordinated exchange, in turn, enables higher productivity and higher quality performance (Dutton \& Heaphy, 2003; Losada, 1999; Fredrickson, Mancuso, Branigan, \& Levenson, 1998).

Enabling Positive Communication. Because bad is stronger than good, and most organizations are fraught with problems and challenges, prescribing positive communication is much easier than practicing it. One obvious way that responsible leaders can enable positive communication is by exemplifying positive talk themselves. Minimizing criticism and negativity, and replacing it with compliments and supportive communication, can enable positive communication to flourish. Leaders' role modeling has a disproportionate affect on creating such outcomes (George, 1998). Aside from role modeling, however, two specific levers are available to responsible leaders to enabling positive communication: the reflected best self feedback process (Roberts, Dutton, Spreitzer, Heaphy, \& Quinn, 2003) and the use of supportive communication (Cameron, 2002b).

The reflected best self feedback process is a technique used to capture positive feedback for individuals - to encourage positive communication —and then guide people through a process of uncovering their strengths and the positive evaluations held by others about them. The technique was developed at the University of Michigan and is now being used in several universities and corporations. Each person (e.g., student, employee, manager) is asked to identify approximately 20 other people who are acquaintances. These can be friends, co-workers, neighbors, or family members. Each of these acquaintances is asked to write three stories in response to the question: "When you have seen me at my best, what unique value did I create?" Or, alternatively, "When you have seen me make a special contribution, what unique strengths did I display?" In other words, the 20 acquaintances write three stories about when this person was his or her best self. Those 60 stories identify the key strengths and unique talents of the individual-information that is both rare and extremely valuable. The communication is universally positive, and the concomitant positive affect naturally follows (Roberts, Dutton, Spreitzer, Heaphy, \& Quinn, 2004).

This positive communication is analyzed by the person receiving the stories and is summarized into a few key themes. Those themes represent the best-self strengths and uniquenesses of the person, and strategies for capitalizing on these strengths are then formulated. The feedback comes in the form of incidents and stories, not numbers or trend lines, so it is connected directly to behaviors that the person has displayed in the past and which can be repeated and enhanced in the future. It captures emotions and feelings as well as intentional actions. These are the strengths that can be built upon and enhanced. This kind of feedback does not even mention weaknesses or shortcomings, so it does not motivate people to focus on areas of deficiency. Instead, recipients have strengthened relationships with feedback givers, feelings of reciprocity toward them, an enhanced desire to live up to the positive best self descriptions, elevated positive affect, and a reinterpretation of past personal history to be more strengthbased.

Of course, completely ignoring weaknesses and inadequacies is not healthy, and focusing exclusively on the positive and disregarding critical weaknesses is not apt to be productive in the long-run. It is just that most individuals, and most organizations, concentrate overwhelmingly on the negative, and they are likely to ignore, or at least to short-change, the positive. The reflective best-self feedback technique is a way to counterbalance that tendency by encouraging positive communication.

A second means by which responsible leaders can enable positive communication is by using supportive communication, particularly when corrective, critical, or negative messages must be delivered. All communication cannot be complimentary, agreeable, or congratulatory, of course, and negative messages must be delivered in any organization or relationship. Therefore, certain communication techniques-all designed to preserve and strengthen a positive relationship between communicators while still addressing problems and concerns-are available in order to maintain the advantages of positive communication (Cameron, 2002b; Gibb, 1961; Knapp \& Vangelisti, 1996). Of the eight elements 
of supportive communication, the one most apropos in this context is the use of description rather than evaluation in identifying and resolving problems (Rogers, 1961). Specifically, when delivering negative messages, describing a situation (rather than evaluating it), identifying objective consequences or personal feelings about it (rather than blaming), and suggesting an acceptable alternative (rather than arguing about who is right) leads to a constructive conversation that focuses on identifying commonalities and collaboration rather than adversarial communication (Gibb, 1961; Cameron 2002b). Supportive communication, in other words, allows individuals to deliver critical or disapproving messages while, at the same time, strengthening the positive relationship with the receiver. Responsible leaders who facilitate positive communication can use these two strategies to help achieve their desired results.

Positive Calling Orientation. Wrzesniewski (2003), citing research in sociology (Bellah, Madsen, Sullivan, Swidler \& Tipton, 1985) and psychology (Baumeister, 1991; Schwartz, 1994) pointed out that individuals typically hold one of three broad orientations toward work: work as a job, as a career, or as a calling. Those who see work as a job do their work primarily for the financial or material rewards it provides. They take no particular personal satisfaction from their work, and they pursue their own interests and passions in non-work contexts. In contrast, individuals with a career orientation are motivated by success. They work to achieve the prestige, power, recognition, and advancement that come from performing their work well. They desire to be exemplary members of their profession, and they use work to develop more personal capability and notoriety. The third orientation, the sense of work as a calling, motivates individuals to work for the sake of the work itself. The actual tasks involved in their work provide intrinsic benefit and profound meaning. They consider work inherently fulfilling, and they seek for a greater good, regardless of any material rewards offered by work.

Paralleling these work orientations are three types of relationships between members and their organizations: compliance, identification, and internalization (Kelman, 1958; O'Reilly \& Chatman, 1996). A compliance relationship produces desired behaviors through punishments and rewards. That is, compliant individuals act for personal material benefit and do not necessarily believe in the content of the action they take (a job orientation). Identification motivates individuals to further or to maintain a relationship with the organization, so that individuals are committed to what they are doing as organizational members. Actions are taken to procure the satisfaction of belonging and to reinforce a sense of membership (a career orientation). Internalization is the most profound adoption of organizational goals. Individuals who have internalized the organizational culture and mission have accepted that what they are doing is the right thing to do. Internalization leads individuals to adopt the organization's purposes and priorities as their own (a calling orientation).

The predominance of calling orientations (or internalization in organizations) is associated with more positive outcomes and superior individual and organizational performance. For example, workers with a calling orientation reported higher job and life satisfaction scores compared to those with career or job orientations, as well as high satisfaction with their organization and their work (Wrzesniewski, McCauley, Rozin, \& Schwartz, 1997). A stronger identification with the work unit accompanied a calling orientation, as did higher levels of trust and confidence in management, higher levels of commitment, less conflict, more satisfactory relationships with co-workers, and higher levels of satisfaction with the work itself (Taylor \& Bowers, 1972; Cook \& Wall, 1980; Mowday, Steers, \& Porter, 1980). Since the mean correlation between job satisfaction and performance is 0.30 - as determined by a definitive metaanalysis (Judge, Thoreson, Bono, and Patton, 2001) — higher satisfaction scores are likely to be associated with higher performance. In fact, higher levels of organizational performance were detected in health care organizations when callings predominated among employees (Wrzesniewski \& Landman, 2000).

It is important to remember that this sense of calling is not dependent on the type of work performed but on the interpretation of the profound meaning inherent in the work (Bellah et al., 1985; Wrzesniewski, 2003). Any kind of work - even that typically thought of as physically, socially, or morally tainted — can be reframed in a positive light (Ashforth \& Kreiner, 1999). Put another way, exactly the same task may be viewed as a calling or a job, depending on the perspective of the individual. For example, in a study of custodians in a Midwest hospital (Wrzesniewski \& Dutton, 2001) researchers interviewed a staff member who was assigned to clean up vomit and excrement from the oncology ward when patients came in for 
chemotherapy. These patients lost control of bodily functions when they were subjected to doses of medications needed to treat their malignancies. This staff member's response to her work was something like this: "My job is equally important to the physician. I help these people feel human. At their lowest and most vulnerable point, I help them maintain their dignity. I make it okay to feel awful, to lose control, and to be unable to manage themselves. My role is crucial to the healing process." Even the most noxious and unpleasant of tasks can be reinterpreted as a calling.

Enabling a Positive Calling Orientation. Enabling a positive work orientation through a sense of calling among employees is enhanced by helping them identify a sense of meaningfulness in their work. Responsible leaders enable this kind of orientation-where callings and internalization are dominant characteristics of the workforce - through at least four mechanisms reviewed by Pratt and Ashforth (2003). These include: (1) job enrichment and job involvement (Lodahl \& Kejner, 1965; Hackman \& Oldham, 1980), meaning that work is designed so as to provide enrichment and involvement (through skill variety, task identity, task significance, autonomy, and feedback). Work designed to provide personal growth and development opportunities is almost always more meaningful than routine work. Several strategies to achieve these work attributes have been identified by Hackman and Oldham (1980). (2) the presence of intrinsic motivational factors such as interesting work, opportunities for creativity, chances for advancement and achievement, peer recognition, and personally fulfilling goals (Herzberg, Mausner, \& Snyderman, 1959; Kanungo \& Hartwick, 1987; Amabile, Hill, Hannessey, \& Tighe, 1994). Intrinsic motivation refers to factors that are internally and inherently motivational, whereas extrinsic factorsincluding pay, working conditions, or promotions_-are less powerful as motivational agents(Deci \& Ryan, 1985). Intrinsic factors are associated with a calling orientation, and responsible leadership strategies for achieving these results are enumerated by Pratt \& Ashforth (2003). (3) creating an empowering environment, including opportunities to develop self-efficacy (a sense of competence), self-determination (a sense of choice), consequence (a sense of impact), meaningfulness (a sense of purpose), and trust (a sense of security) (Spreitzer, 1992; Mishra, 1992). The performance differences between organizations that enable these five dimensions of empowerment and normal organizations are significant both for individual performance and for organizational outcomes. Cameron (2002c) offered a large number of strategies available for leaders to enhance and enable empowerment. (4) articulating a clear vision of the future which is based on source credibility (Kousner \& Posner, 1988), optimism and positive emotions (Fredrickson, 2003), and being interesting (Davis, 1971), meaning that the vision focuses on abundance and opportunity rather than problems or obstacles (Cooperrider \& Sekerka, 2003; Powley, Fry, Barrett, \& Bright, 2004). Focusing the vision on encouraging and enabling the highest potential has substantially different meaning than vision statements that are focused on beating the competition, achieving a number one ranking, and meeting or beating challenges or competitive pressures. Ashforth and Kreiner (1999) presented several strategies for achieving this end.

Responsible leaders enable a positive calling orientation, in other words, by emphasizing the profound purpose, the meaningfulness, and the vision of abundance that triggers intrinsic motivation in people. Research clearly supports the connection between these enabling factors and a sense of calling in and at work (also sees Pratt \& Ashforth, 2003).

\section{Conclusion and Research Questions}

This discussion has pointed out that responsible leadership can be thought of in three different ways-as accountability, as discretion and freedom, or as enabling appropriate outcomes. Identifying some strategies to facilitate the latter of these three definitions has been the focus of this chapter. Specifically, responsible leadership is located in the domain of Positive Organizations Scholarship, and some of the recent literature connected with that field of study has been used to show how a focus on positive dynamics produces extraordinarily positive results. This is in spite of the fact that negative phenomena tend to dominate the attention of individuals and organizations. Because "bad is stronger than good," mindful and conscientious effort must be placed on positive phenomena in order for the performance benefits to occur. This positive emphasis is contrary to natural tendencies in individuals and organizations. Responsible leadership, in other words, is counterintuitive in that it enhances and enables that which elevates rather than that which overcomes problems. 
Four strategies were identified in Figure 1 and research related to each was reviewed. These four strategies are among those that characterize responsible leadership and which enable especially positive outcomes-, positive climate, positive connections, positive communication, and positive calling orientation. These four strategies are not comprehensive, of course, but they illustrate the levers available to leaders who wish to enable positive outcomes. The empirical evidence certainly supports the legitimacy of these strategies.

Research on responsible leadership, of course, is still much underdeveloped in terms of empirical research findings and theoretical maturity. Hence, several important research questions are offered to help guide future research endeavors. For example:

Concept Definition: Responsibility and leadership are the subjects of almost 50,000 books, based on a quick scan of Amazon.com. Seldom, however, are the two concepts carefully and precisely defined and measured. The volume of prescriptions far outweighs the volume of credible evidence. A variety of research questions remain unaddressed, such as: How do we know responsibility when we see it? What is and is not responsible leadership in the POS sense? What are the downsides of a focus on the positive? Can organizations succeed without responsible leadership, or can they succeed with responsible leadership? How much or how little can be tolerated? What is goodness and appropriateness? Who decides? The central concepts, in other words, provide fruitful territory for more thorough investigations.

Level of Analysis: Do the individual dynamics enabled by responsible leaders reproduce themselves in organizations, and vice versa? Why or why not? For example, do positive relationships among individuals have the same kinds of effects on networks of organizations? Do individual interpretations of meaningfulness at work produce a sense of meaningfulness in the work of the organization? In what way does positive communication and using reflected best self feedback affect organization level performance? Demonstrating relationships at one level of analysis does not necessarily mean that they will be present in another, and responsible leadership's impact on individuals may be different than on organizations.

Measurement: Few instruments, methods, or reliable indicators have been developed to assess positive phenomena. For example, how should responsibility, or leadership, be assessed? How are positive concepts and variables best identified, measured, and explained? What are the key indicators? A need exists to locate and measure the existence of extraordinarily positive states, processes, structures, and behavior. What are the markers? Questions relating to what is measured as well as how it is measured are clearly in need of investigation.

New Concepts and New Relationships: Several nontraditional concepts have been discussed in this chapter in relation to responsible leadership including positive energy, organizational virtuousness, strengths, positive deviance, positive social relationships, positive climate, meaningfulness, and so on. Few of these concepts have been carefully or thoroughly examined, yet they represent a sampling of positive factors that may be associated with responsibility and with leadership. What other aspects of responsible leadership behavior have not been taken into account in explaining positive outcomes? What other environmental, organizational, or individual factors might affect positive organizational and individual outcomes? Since most empirical studies account for small percentages of the variance in individual and organizational outcomes, additional variables surely can be uncovered.

Causality: Questions relating to causal directionality are always fruitful areas for investigation, and especially in responsible leadership and positive outcomes. That is, what are the causal relationships (directionality) associated with various positive phenomena? Do positive relationships lead to cardiovascular fitness, or vice versa? Which comes first, virtuousness (e.g., compassion, forgiveness, gratitude) or high performance in organizations? Longitudinal studies are always difficult to conduct, but they would provide important insights about the effects of responsible leadership that heretofore are only assumed. 
Enablement: In addition to questions of causal association, issues relating to the enablement of positive outcomes also are salient. Uncovering why and how responsible leadership occurs-and how it affects others-is an under-investigated issue. For example, aside from leadership, what are the attributes of the structures, processes, cultures, and/or resources that are most conducive to, or resistant to, positive dynamics in organizations? What kinds of organizational arrangements are conducive to high quality relationships, positive energy development, positive climates, or the enablement of responsible leadership? What organizational conditions facilitate the development of emotional competence, positive communication, or bring forth the best in people? Studies of enablement, unlike "best-practice" approaches, seek to identify the processes and mechanisms that enable and encourage positive deviance, responsibility, and leadership.

Thus, returning to where the chapter began-i.e., whereas the idea of responsible leadership is not new and the literature on effective leadership has always been characterized by an element of responsibilitythe scholarly study of both concepts—responsibility and leadership-is in need of systematic attention. Responsibility in the sense of appropriateness and goodness is both under-investigated and largely misunderstood, and leadership as a temporary state rather than a permanent attribute or condition requires a rethinking in leadership research. Hopefully, this chapter will stimulate alternative thinking and new venues for investigation, as well as providing guidelines for workable strategies. 


\section{References}

Amabile, T. M., R. Conti, H. Coon, J. Lazenby \& M. Herron (1996), 'Assessing the work environment for creativity', Academy of Management Journal, 39, 1154-1184.

Amabile, T. M., T. M. Hill, B. A. Hennessey \& E. M. Tighe (1994), 'The work preference inventory: Assessing intrinsic and extrinsic motivational orientations', Journal of Personality and Social Psychology, 66, 950-967.

Ashforth, B. E. \& G. E. Kreiner (1999), "'How can you do it?" Dirty work and the challenge of constructing a positive identity', Academy of Management Review, 24(3), 413-434.

Baker, W. (2000) Achieving success through social capital. San Francisco: Jossey Bass.

Baker, W. (2004) Half-baked brown bag presentation on positive energy networks. Unpublished manuscript, University of Michigan Business School.

Baker, W. R. Cross, \& M. Wooten (2003) 'Positive organizational network analysis and energizing relationships.' in K. S. Cameron, J. E. Dutton \& R. E. Quinn (eds.), Positive Organizational Scholarship, San Francisco, CA: Berrett-Koehler Publishers Inc., pp. 328-342.

Bargh, J. A. \& T. L. Chartrand (1999), 'The unbearable automaticity of being', American Psychologist, 54(7), 462-479.

Batson, C. D. (1994), 'What act for the public good? Four answers', Personality and Social Psychology Bulletin, 20(Special Issue: The Self and the Collective), 603-610.

Baumeister, R. F. (1991), Meanings of life, New York, NY: Guilford Press.

Baumeister, R. F., E. Bratslavsky, C. Finkenauer \& K. D. Vohs (2001), 'Bad is stronger than good', Review of General Psychology, 5(4), 323-370.

Bellah, R. N., R. Madsen, W. M. Sullivan, A. Swidler \& S. M. Tipton (1985), Habits of the heart: Individualism and commitment in American life, New York, NY: Harper \& Row.

Berkman, L.F., L. Leo-Summers, \& R.I. Horowitz (2002) 'Emotional support and survival after myocardial infarction: A prospective, population-based study of the elderly. In Cacioppo, J.T. et al. (eds.) Foundations in social neuroscience. Cambridge, MA: MIT Press.

Bolino, M. C., W. H. Turnley \& J. M. Bloodgood (2002), 'Citizenship behavior and the creation of social capital in organizations', Academy of Management Review, 27, 505-522.

Bollier, D. (1996) Aiming higher: Twenty-five stories of how companies prosper by combining sound management and social vision. New York: Amacom.

Brondolo, E. R. Rieppi, S.A. Erickson, E. Bagiella, P.A. Shapiro, P. McKinley, \& R.P. Sloan (2003) 'Hostility, interpersonal interactions, and ambulatory blood pressure.' Psychosomatic Medicine, 65, 1003-1011.

Brown, R. (1986), 'Attribution theory', Social psychology, New York, NY: Free Press, pp. 131-194.

Bruner, J. S. \& J. J. Goodnow (1956), A study of thinking, New York, NY: John Wiley \& Sons, Inc.

Buckingham, M. \& D. Clifton (2001) Now, discover your strengths. New York: Free Press.

Burns, James McGregor (1978) Leadership. New York: Harper \& Row.

Burt, R. (1992) Structural holes. Cambridge, MA: Harvard Business School Press.

Cameron, K.S. (2002a) 'Managing personal stress.' in Whetten, D.A. and K.S. Cameron Developing management skills. Upper Saddle River, NJ: Prentice Hall. pp. 97-154.

Cameron, K.S. (2002b) 'Coaching, counseling, and supportive communication.' in Whetten, D.A. and K.S. Cameron Developing management skills. Upper Saddle River, NJ: Prentice Hall. pp. 211-250.

Cameron, K.S. (2002c) 'Empowering and delegating," in Whetten, D.A. and K.S. Cameron, Developing management skills. Upper Saddle River, NJ: Prentice Hall. pp. 405-450.

Cameron, K.S. (2003) 'Organizational virtuousness and performance.' in K. S. Cameron, J. E. Dutton \& R. E. Quinn (eds.), Positive Organizational Scholarship, San Francisco, CA: Berrett-Koehler Publishers Inc., pp. 48-65.

Cameron, K. S., D. Bright, \& A. Caza (2004), 'Exploring the relationships between organizational virtuousness and performance', American Behavioral Scientist, 47(6), 766-790.

Cameron, K. S. \& A. Caza (2002), 'Organizational and leadership virtues and the role of forgiveness', Journal of Leadership and Organizational Studies, 9(1), 33-48.

Cameron, K. S., J. E. Dutton \& R. E. Quinn (eds.) (2003). Positive organizational scholarship. San Francisco, CA: Berrett-Koehler Publishers Inc. 
Chappell, T. (1999), Managing upside down: The seven intentions of value-centered leadership, Boston, MA: William Morrow.

Clifton, D. O. \& J. K. Harter (2003), 'Investing in strengths', in K. S. Cameron, J. E. Dutton \& R. E. Quinn (eds), Positive Organizational Scholarship, San Francisco, CA: Berrett-Koehler Publishers Inc., pp. 111-121.

Cohen, S., W.J. Doyle, D. Skoner, B.S. Rabin, \& J.M. Gwaltney (1997) 'Social ties and susceptibility to the common cold.' JAMA, 277: 1940-1944.

Cook, J. \& T. D. Wall (1980), 'New work attitude measures of trust, organizational commitment, and personal need non-fulfillment', Journal of Occupational Psychology, 53, 39-52.

Cooperrider, D. L. \& D. Whitney (1999), Appreciative inquiry, San Francisco, CA: Berrett-Koehler.

Cooperrider, D.L. \& L.E. Sekerka (2003) 'Toward a theory of positive organizational change.' in K. S. Cameron, J. E. Dutton \& R. E. Quinn (eds.), Positive Organizational Scholarship, San Francisco, CA: Berrett-Koehler Publishers Inc., pp. 225-240.

Cooperrider, D.L. and S. Srivastva (1987) "Appreciative inquiry in organizational life." Research in Organizational Change and Development, 1: 129-169.

Cowen, E. L. \& R. P. Kilmer (2002), 'Positive psychology: Some plusses and some open issues', Journal of Community Psychology, 30, 449-460.

Czapinski, J. (1985), 'Negativity bias in psychology: An evaluation of Polish publications', Polish Psychological Bulletin, 16, 27-44.

Davis, M. S. (1971), 'That's interesting! Towards a phenomenology of sociology and a sociology of phenomenology', Philosophy of the Social Sciences, 1, 309-344.

Deci, E. \& Ryan, R. (1985) Intrinsic motivation and self-determination in human behavior. New York: Plenum.

Denison, D. R. (1996), 'What is the difference between organizational culture and organizational climate? A native's point of view on a decade of paradigm wars', Academy of Management Review, 21(3), 619-654.

Derber, C. (2000) Corporate Nation: How Corporations Are Taking Over Our Lives and What We Can Do About It. New York: Griffin.

Diener, E. (1995) "Factors predicting the subjective well-being of nations." Journal of Personality and Social Psychology, 69: 851-864.

Dutton, J.E. (2003) Energizing your workplace: Building and sustaining high quality relationships at work. San Francisco: Jossey-Bass.

Dutton, J. E., P. J. Frost, M. C. Worline, J. M. Lilius \& J. M. Kanov (2002), 'Leading in times of trauma', Harvard Business Review (January), 54-61.

Dutton, J. E. \& E. D. Heaphy (2003), 'The power of high-quality connections', in K. S. Cameron, J. E. Dutton \& R. E. Quinn (eds.), Positive Organizational Scholarship, San Francisco, CA: BerrettKoehler Publishers Inc., pp. 263-278.

Emmons, R. A. (2003), 'Acts of gratitude in organizations', in K. S. Cameron, J. E. Dutton \& R. E. Quinn (Eds), Positive Organizational Scholarship, San Francisco, CA: Berrett-Koehler Publishers Inc., pp. 81-93.

Enterprise, B. T. (1991), 'Merck and company', in P. Werhane (ed.), Ethical Issues in Business: A Philosophical Approach, Upper Saddle River, NJ: Prentice-Hall, pp. 215-220.

Epel, E., B.S. McEwen, \& J.R. Ickovics (1998) 'Embodying psychological thriving: Physical thriving in response to stress.' Journal of Social Issues, 54, 301-322.

Esterling, B.A., J.K. Kiecolt-Glaser, J. Bodnar, \& R. Glaser (1994) 'Chronic stress, social support, and persistent alteractions in the natural killer cell response to Cytokines in older adults.' Health Psychology, 13, 291-299.

Fedarko, K. (2003), 'He fights terror with books', Parade, 6(April), 4-6.

Fredrickson, B. L. (1998), 'What good are positive emotions?' Review of General Psychology, 2, 300-319.

Fredrickson, B. L. (2001), 'The role of positive emotions in positive psychology: The broaden-and-build theory of positive emotions', American Psychologist, 56, 218-226.

Fredrickson, B. L. (2002), 'Positive emotions', in C. R. Snyder, \& S. J. Lopez (eds), Handbook of Positive Psychology, New York, NY: Oxford University Press, pp. 120-134.

Fredrickson, B. L. (2003), 'Positive emotions and upward spirals in organizations', in K. S. Cameron, J. E. Dutton \& R. E. Quinn (eds), Positive Organizational Scholarship, San Francisco, CA: BerrettKoehler Publishers Inc., pp. 163-175. 
Fredrickson, B. L. \& C. Branigan (2001), 'Positive emotions', in T. J. Mayne, \& G. A. Bonnano (eds), Emotions: Current issues and future directions, New York, NY: Guilford, pp. 123-151.

Fredrickson, B. L. \& R. W. Levenson (1998), 'Positive emotions speed recovery from the cardiovascular sequelae of negative emotions', Cognition and Emotion, 12, 191-200.

Fredrickson, B. L., R. A. Mancuso, C. Branigan \& M. M. Tugade (2000), 'The undoing effect of positive emotions', Motivation and Emotion, 24(4), 237-259.

Frost, P.J. (1999) 'Why compassion counts.' Journal of Management Inquiry, 8, 127-133.

George, J. M. (1998), 'Salesperson mood at work: Implications for helping customers.' Journal of Personal Selling and Sales Management, 18, 23-30.

Gibb, J. R. (1961), 'Defensive communication', Journal of Communication, 11, 141-148.

Gottman, J. M. (1994), What predicts divorce: The relationship between marital processes and marital outcomes, New York, NY: Lawrence Earlbaum.

Hackman, J. R. \& G. R. Oldham (1980), Work design, Reading, MA: Addison-Wesley.

Heaphy, E.D. \& J.E. Dutton (2004) 'Embodied connections: Understanding the physiological effects of positive connections at work.' Working paper, Center for Positive Organizational Scholarship, University of Michigan Business School.

Herzberg, F., B. Mausner \& B. B. Snyderman (1959), The motivation to work, New York, NY: Wiley.

Holt-Lunstad, J., B.N. Uchino, T.W. Smith, C. Olsen-Cerny, \& J.B. Nealey-Moore (2003) 'Social relationships and ambulatory blood pressure: Structural and qualitative predictors of cardiovascular function during everyday social interactions.' Health Psychology, 22, 388-397.

Hursthouse, R. (1999) On virtue ethics. Oxford: Oxford University Press.

Ibarra, H. (1993) 'Network centrality, power, and innovation involvement: Determinants of technical and administrative roles.' Academy of Management Journal, 36, 471-501.

Isen, A. M. (1987), 'Positive affect, cognitive processes, and social behavior', Advances in Experimental Social Psychology, 20, 203-253.

Judge, T. A., C. J. Thoreson, J. E. Bono \& G. K. Patton (2001), 'The job satisfaction-job performance relationship: A qualitative and quantitative review', Psychological Bulletin, 127(3), 376-407.

Kanov, J.M., S. Maitlis, M.C. Worline, J.E., Dutton, P.J. Frost, \& J.M. Lilius (2004) 'Compassion in organizational life.' American Behavioral Scientist, 47, 808-827.

Kanungo, R. N. \& J. Hartwick (1987), 'An alternative to the intrinsic-extrinsic dichotomy of work rewards', Journal of Management, 13, 751-766.

Karlin, W.A., E. Brondolo, \& J. Schwartz (2003) 'Workplace social support and ambulatory cardiovascular activity in New York City traffic agents.' Psychosomatic Medicine, 65, 167-176.

Kelman, H. C. (1958), 'Compliance, identification, and internalization: Three processes of attitude change', Conflict Resolution, 2(1), 51-60.

Kiecolt-Glaser, J.K., C. Bane, R. Glaser, \& W.B. Malarkey (2003) 'Love, marriage, and divorce: Newlywed's stress hormones foreshadow relationship changes.' Journal of Counseling and Clinical Psychology, 70, 537-547.

Knapp, M. L. \& A. L. Vangelisti (1996), Interpersonal communication and human relationships, Boston, MA: Allyn \& Bacon.

Kouzes, J.M. and B.Z. Posner (1988) What followers expect from leaders: How to meet people's expectations and build credibility. San Francisco: Jossey-Bass, 1988.

Kram, K. (1985) Mentoring at work: Developing relationships in organizational life. Glenview, IL: Scott Foresman.

Lodahl, T. M. \& M. Kejner (1965), 'The definition and measurement of job involvement', Journal of Applied Psychology, 49, 24-33.

Losada, M. (1999), 'The complex dynamics of high performance teams', Mathematical and Computer Modelling, 30, 179-192.

Losada, M. \& E. D. Heaphy (2004), 'Positivity and connectivity', American Behavioral Scientist, 47(6).

March, J. G. \& H. A. Simon (1958), Organizations, New York, NY: John Wiley \& Sons, Inc.

Margolis, J. D. \& J. P. Walsh (2003), 'Misery loves companies: Rethinking social initiatives by business', Administrative Science Quarterly, 48, 268-305.

Mayne, T. T. (1999), 'Negative affect and health: The importance of being earnest', $\underline{\text { Cognition and }}$ Emotion, 13, 601-635.

McCullough, M. E., K. I. Pargament \& C. Thoreson (2000), Forgiveness: Theory, research, and practice, New York, NY: Guilford. 
McCullough, M.E., R.A. Emmons, \& J. Tsang (2002) 'The grateful disposition: A conceptual and empirical topography.' Journal of Personality and Social Psychology, 82, 112-127.

Medalie, J.H. \& U. Goldbourt (1976) 'Angina pectoris among 10,000 men: Psychological and other risk factors as evidenced by a multivariate analysis of a five year incidence study. The American Journal of Medicine, 60, 910-921.

Mishra, A. K. (1992), Organizational response to crisis: The role of mutual trust and top management teams, Unpublished doctoral dissertation. University of Michigan Business School.

Mowday, R. T., R. M. Steers \& L. W. Porter (1979), 'The measurement of organizational commitment', Journal of Vocational Behavior, 14, 224-247.

O'Reilly, C. A. \& J. A. Chatham (1996), 'Culture as social control: Corporations, cults, and commitment', in B. M. Staw, \& L. L. Cummings (eds), Research in Organizational Behavior (Vol. 18), Greenwich, CT: JAI Press, pp. 157-200.

Peterson, C. M. \& M. E. P. Seligman (2003), 'Positive organizational studies: Lessons from positive psychology', in K. S. Cameron, J. E. Dutton \& R. E. Quinn (eds.), Positive Organizational Scholarship, San Francisco, CA: Berrett-Koehler Publishers Inc., pp. 14-28.

Powley, E. H., R. E. Fry, F. J. Barret \& D. S. Bright (2004), 'Egalitarian participation meets command and control: Democratic transformation through the Appreciative Inquiry summit', Academy of Management Executive, in press.

Pratt, M. G. \& B. E. Ashforth (2003), 'Fostering meaningfulness in working at work', in K. S. Cameron, J. E. Dutton \& R. E. Quinn (eds.), Positive Organizational Scholarship, San Francisco, CA: BerrettKoehler Publishers Inc., pp. 309-327.

Quinn, R. E. (2004), Building the bridge as you walk on it: A guide to leading change, San Francisco, CA: Jossey-Bass.

Riley, S. (1998) Critical thinking and problem solving. Upper Saddle River, NJ: Prentice Hall.

Roberts, L.M., J.E. Dutton, G. Spreitzer, E.D. Heaphy, \& R.E. Quinn, (2004) 'Composing the reflected best-self portrait: Building pathways for becoming extraordinary in work organizations.' Center for Positive Organizational Scholarship, University of Michigan Business School Working Paper.

Rogers, C.W. (1961) On becoming a person. Boston: Houghton Mifflin.

Ryff, C. D. \& B. Singer (eds.). (2001). Emotion, social relationships, and health. Oxford, UK: Oxford University Press.

Ryff, C.D., B. Singer, E. Wing, \& G.D. Love (2001) 'Elected affinities and uninvented agonies: Mapping emotion with significant others onto health.' In Ryff, C.D. \& B. Singer (eds.) Emotion, social relationships, and health. New York: Oxford University Press. pp. 133-175.

Salancik, G. R. \& J. R. Meindl (1984), 'Corporate attributions as strategic illusions of management control', Administrative Science Quarterly, 29(2), 238-254.

Schottenstein, A. (2003), Virtue and organizations, Senior research project. University of Michigan Undergraduate Research Opportunity Program.

Schwartz, B. (1994), The costs of living: How market freedom erodes the best things in life, New York, NY: W. W. Norton.

Schwartz, J. (2002), Dean's Lecture Series. University of Michigan Business School.

Seeman, T. (2001) 'How do others get under our skin? Social relationships and health.' In Ryff, C.D. \& B. Singer (eds.) Emotion, social relationships, and health. New York: Oxford University Press. Pp. 189-210.

Seligman, M. E. P. (2002), 'Positive psychology, positive prevention, and positive therapy', in S. J. Lopez (ed), Handbook of Positive Psychology, New York, NY: Oxford University Press, pp. 3-9.

Smidts, A., A. T. H. Pruyin \& C. B. M. Van Riel (2001), 'The impact of employee communication and perceived external prestige on organizational identification', Academy of Management Journal, 44(5), 1051-1062.

Snyder, C. R. \& S. J. Lopez (2002), Handbook of positive psychology, New York, NY: Oxford University Press.

Spreitzer, G. M. (1992), When organizations dare: The dynamics of individual empowerment in organizations, Unpublished doctoral dissertation. University of Michigan Business School.

Staw, B. M. \& S. G. Barsade (1993), 'Affect and managerial performance: A test of the sadder-but-wiser versus happier-and-smarter hypotheses', Administrative Science Quarterly, 38, 304-331. 
Stone, A.A., E.S. Mezzacappa, B.A. Donatone, \& M. Gonder (1999) 'Psychosocial stress and social support are associated with prostate-specific antigen levels in men: Results from a community screening program.' Health Psychology, 18: 482-486.

Taylor, S.E. (2002) The tending instinct: How nurturing is essential for who we are and how we live. New York: Time Books.

Taylor, J. C. \& D. G. Bowers (1972), Survey of organizations: A machine scored standardized questionnaire instrument, Ann Arbor, MI: Institute for Social Research, University of Michigan.

Tjeltveit, A.C. (2004) 'Implicit virtues, divergent goods, multiple communities,' American Behavioral Scientist, 47, 395-414.

Uchino, B.N., J.K. Kiecolt-Glaser, , \& J.T. Cacioppo (1992) 'Age related changes in cardiovascular response as a function of a chronic stressor and social support.' Journal of Personality and Social Psychology, 63, 839-846.

Unden, A.L., K. Orth-Gomer, \& S. Elofsson (1991) 'Cardiovascular effects of social support in the work place: Twenty-four-hour ECG monitoring of men and women.' Psychosomatic Medicine, 53, 5060.

Walsh, J. P. (1999), 'Business must talk about its social role', in T. Dickson (ed), Mastering Strategy, London, UK: Prentice Hall, pp. 289-294.

Walsh, J.P., K. Weber, and J.D. Margolis (2003) 'Social issues and management: Our lost cause found.' Journal of Management, 29, 859-881.

Weick, K. E. (2003), 'Positive organizing and organizational tragedy', in K. S. Cameron, J. E. Dutton \& R. E. Quinn (eds.), Positive organizational scholarship, San Francisco, CA: Berrett-Koehler Publishers Inc., pp. 66-80.

Whetten, D. A. \& K. S. Cameron (2002), Developing management skills, Upper Saddle River, NJ: Prentice Hall.

Worthington, E. L. (1998), Dimensions of forgiveness: Psychological research and theological perspectives, Philadelphia, PA: Templeton Foundation Press.

Wrzesniewski, A. (2003), 'Finding positive meaning in work', in K. S. Cameron, J. E. Dutton \& R. E. Quinn (eds), Positive Organizational Scholarship, San Francisco, CA: Berrett-Koehler Publishers Inc., pp. 296-308.

Wrzesniewski, A. \& J. E. Dutton (2001), 'Crafting a job: Revisioning employees as active crafters of their work', Academy of Management Review, 26(2), 179-201.

Wrzesniewski, A. \& J. Landman. (2000), Occupational choice and regret: Decision antecedents and their outcomes, Unpublished manuscript.

Wrzesniewski, A., C. R. McCauley, P. Rozin \& B. Schwartz (1997), 'Jobs, careers, and callings: People's relations to their work', Journal of Research in Personality, 31, 21-33.

Yukl, G., A. Gordon \& T. Taber (2002), 'A hierarchical taxonomy of leadership behavior: Integrating a half century of behavior research', Journal of Leadership and Organizational Studies, 9(1), 15-31. 
Figure 1. Four Strategies for Responsible Leadership

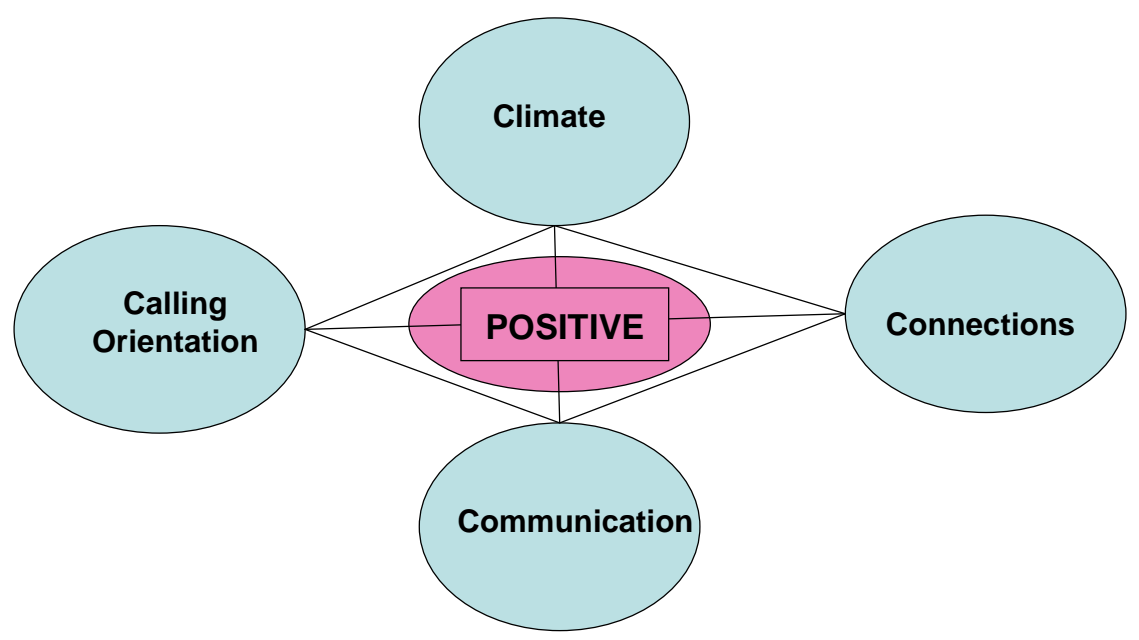

